\title{
Pendidikan Responsif Gender dan Kesehatan Reproduksi dalam Proses Pembelajaran
}

\author{
Nur Wiarsih1*, I Gede Astawan ${ }^{2}$ \\ ${ }^{1}$ Prodi PGMI Institut Agama Islam Ibrahimy Genteng Banyuwangi, Banyuwangi, Indonesia \\ 2 Prodi PGSD Fakultas Ilmu Pendidikan Universitas Pendidikan Ganesha
}

\section{ART ICLE INFO}

Article history:

Received June 19, 2021

Revised June 20, 2021

Accepted July 30, 2021

Available online August 25, 2021

Kata Kunci:

Pendidikan Responsif Gender,

Kesehatan Reproduksi

Keywords:

Gender Responsive Education, Reproductive Health

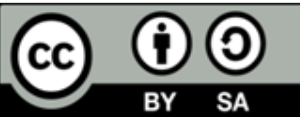

This is an open access article under the CC BY-SA license.

Copyright $(2021$ by Author. Published by Universitas Pendidikan Ganesha.

\begin{abstract}
A B S T R A K
Kondisi di sekolah pada umumnya menunjukkan masih adanya ketimpangan peran gender dalam proses pembelajaran. Ketimpangan tersebut muncul pada berbagai aspek, antara lain adalah ketersediaan sarana sekolah yang kurang memperhatikan kebutuhan berimbang antara siswa laki-laki dan perempuan, sikap bias gender guru terhadap siswa, materi ajar yang tidak responsif, dan lingkungan belajar yang belum responsif. Penelitian ini bertujuan untuk menganalisis pendidikan responsif gender dan kesehatan reproduksi dalam proses pembelajaran. Penelitian ini menggunakan metode deskriptif kualitatif. Subjek penelitian adalah kepala sekolah dan 7 guru. Teknik pengumpulan data dilakukan melalui wawancara, observasi, dan dokumentasi. Teknik analisis data dilakukan dengan cara mereduksi data, menyajikan data, dan menarik kesimpulan. Hasil penelitian menunjukkan bahwa pendidikan responsif gender dan kesehatan reproduksi yang diimplementasikan melalui merancang pelaksanaan pembelajaran yang responsive, mengintegrasikan pesan gender dan kesehatan reproduksi pada mata pelajaran, dan merancang hidden kurikulum efektif untuk memberikan pemahaman gender dan kesehatan reproduksi bagi siswa di Sekolah Dasar.
\end{abstract}

\section{A B S T R A C T}

Conditions in schools, in general, indicate that there is still an imbalance of gender roles in the learning process. This inequality appears in various aspects, including the availability of school facilities that do not pay attention to the balanced needs of male and female students, the teacher's gender-biased attitude towards students, unresponsive teaching materials, and an unresponsive learning environment. This study aims to analyze gender-responsive education and reproductive health in the learning process. This study used the descriptive qualitative method. The research subjects were the principal and 7 teachers. Data collection techniques were carried out through interviews, observation, and documentation. Data analysis techniques are carried out by reducing data, presenting data, and drawing conclusions. The results showed that gender-responsive education and reproductive health were implemented by designing responsive learning practices, integrating gender and reproductive health messages in subjects, and designing an effective, hidden curriculum to understand gender and reproductive health for students in elementary schools.

\section{PENDAhUluan}

Aspek pendidikan merupakan aspek yang strategis untuk menanamkan nilai-nilai keadilan dan kesetaraan gender. Pendidikan merupakan instrument kunci untuk mempromosikan kesetaraan gender (Dorji, 2020). Melalui pendidikan dapat dikaji dan disampaikan tentang pengetahuan, norma-norma masyarakat, ide-ide, dan nilai-nilai baru termasuk nilai gender. Proses mentransfer nilai-nilai gender tersebut dapat dilakukan secara lugas maupun dalam hidden curriculum. Millenum Development Goal menempatkan gender sebagai tujuan pembangunan ke-5 yang diadopsi oleh pemimpin dunia, yang diharapkan dapat dicapai pada tahun 2030. Oleh karena itu pendidikan responsif gender merupakan konsep yang harus mendapat perhatian (Dary \& Ilyas, 2019; Lee et al., 2019) Pendidikan harus memastikan bahwa semua siswa baik laki-laki maupun perempuan mendapatkan hak-haknya dan tidak mengalami deskrimisasi gender di sekolah (Barreiro-Gen et al., 2021; Tshewang, 2020). 
Kenyataan di lapangan masih ditemukan sekolah-sekolah yang tidak responsif gender dan kesehatan reproduksi dalam melaksanakan proses pembelajaran. Kualitas pembelajaran tidak akan meningkat tanpa memperhatikan kesetaraan gender, meskipun guru telah menggunakan berbagai metode dan strategi pembelajaran di kelas. Kepedulian guru terhadap kesetaraan gender dalam proses pembelajaran pada beberapa sekolah masih rendah (Huntera \& Morrell, 2021). Kondisi di sekolah pada umumnya menunjukkan masih adanya ketimpangan peran gender dalam proses pembelajaran. Ketimpangan tersebut muncul pada berbagai aspek, antara lain adalah ketersediaan sarana sekolah yang kurang memperhatikan kebutuhan berimbang antara siswa laki-laki dan perempuan, sikap bias gender guru terhadap siswa, materi ajar yang tidak responsif, dan lingkungan belajar yang belum responsive (Ratnawati et al., 2019). Masih terbatasnya pengetahuan dan kesadaran tentang pendidikan responsif gender, kebutuhan gender tidak dibahas dalam rencana pembelajaran yang dirancang oleh guru, penggunaan bahan ajar, penggunaan bahasa di kelas, penataan ruang kelas dan interaksi yang dibangun di kelas belum responsif gender (Kahamba, et.al, 2017).

Guru menunjukkan sikap dan harapan yang berbeda terhadap anak laki-laki dan perempuan di sekolah. Banyak kasus ditemukan di mana guru tidak menyadari diskriminasi berdasarkan gender yang telah dilakukan (Abraha, et al. 2019). Penerapan pendidikan responsif gender dipadang tidak efisien jika ditemukan guru yang tidak sadar atau tidak responsif gender (Kahamba, et. al, 2017). Guru yang baik seharusnya meminimalkan kesenjangan dana memaksimalkan berbagai manfaat atau potensi dalam proses pembelajaran untuk semua anak, baik laki-laki maupun perempuan (Wibowo, 2011). Pengetahuan tentang kesehatan reproduksi belum secara utuh dimiliki anak-anak baik dari sisi kesehatan maupun fungsi reproduksi itu sendiri (Hasanah, 2016; Olii et al., 2021). Pendidikan seks dan kesehatan reproduksi bertujuan untuk membimbing serta mengasuh anak laki-laki dan perempuan dalam hal pergaulan antara kelamin dan kehidupan seksual.

Data pengadilan agama Kabupaten Banyuwangi menunjukkan adanya peningkatan perkawinan anak yang disebabkan oleh relasi gender yang tidak sehat, pemahaman tentang kesehatan reproduksi yang tidak tuntas dan ketidakadilan perlakuan terhadap korban kekerasan terutama pada anak perempuan. Jumlah pemohon dispensasi kawin di Kabupaten Banyuwangi pada tahun 2019 menunjukkan terdapat 352 pemohon dispensasi diterima, 4 ditolak, 5 dicabut, 6 digugurkan, 7 dicoret, dan 8 tidak diterima. Sedangkan pada tahun 2020 menunjukkan 980 pemohon dispensasi kawin dikabulkan, 2 ditolak, 13 dicabut, 3 digugurkan, 1 dicoret, 0 tidak diterima (PA Banyuwangi, 2021). Data tersebut selain mengindikasikan bahwa telah terjadi peningkatan pernikahan anak di Kabupaten Banyuwangi juga menunjukkan ketimpangan relasi gender di mana anak-anak korban kekerasan seksual terutama anak perempuan tidak mendapatkan akses pendidikan, setelah mereka menikah/dinikahkan.

Ketidaksetaraan gender dipengaruhi oleh nilai-nilai dan budaya yang melekat pada pola pikir masyarakat (Fujiati, 2016; Ratnawati et al., 2019). Laki-laki dan perempuan ditempatkan pada kedudukan dan peran yang tidak setara, yang mengakibatkan perempuan tidak memiliki akses, kesempatan, dan kontrol dalam proses pembangungan serta tidak memperoleh manfaat yang adil dan setara dengan lakilaki (Fitrianti \& Habibullah, 2012). Sekolah dan lingkungan belajar yang responsif gender adalah sekolah yang memiliki lingkungan akademik, lingkungan sosial, lingkungan fisik dan lingkungan masyarakat sekitarnya mempertimbangkan kebutuhan khusus anak laki-laki dan perempuan. Strategi dan metode mengajar, bahan ajar, manajemen kelas serta pola interaksi antar sesama harus responsif gender. Bangunan sekolah, toilet, ruang kesehatan, tempat duduk kelas, furnitur harus ramah gender (Ratnawati et al., 2019; Tshewang, 2020). Sekolah memiliki keleluasaan untuk mengatur proses pembelajaran dengan tetap memperhatikan tujuan pendidikan nasional dan target-target yang ditentukan oleh pemerintah. Keleluasaan sekolah dalam mengatur proses pembelajaran ini dapat menjadi peluang implementasi pembelajaran responsif gender dan kesehatan reproduksi (Barreiro-Gen et al., 2021; Hasanah, 2016).

Temuan penelitian sebelumnya menyatakan untuk menciptakan kesadaran kepala sekolah dan guru tentang bagaimana memperlakukan anak laki-laki dan perempuan secara adil dalam proses pembelajaran di sekolah merupakan hal yang mendesak (Abraha et al., 2019). Pimpinan sekolah harus memastikan bahwa baik anak laki-laki maupun anak perempuan terlibat dan berada dalam posisi kepemimpinan, kegiatan sekolah, program, diskusi, dan proyek pembelajaran yang diselenggarakan sekolah (Kahamba et al., 2017). Penelitian ini bertujuan untuk menganalisis pendidikan responsif gender dan kesehatan reproduksi dalam proses pembelajaran. SD Lazuardi Tursina Banyuwangi memiliki tagline sebagai sekolah yang berwawasan welas asih, salah satu nilai yang dikembangkan adalah keadilan dan kesetaraan. Proses pembelajaran dilaksanakan dengan memperhatikan gender responsibility. 


\section{METODE}

Penelitian ini adalah penelitian deskriptif kualitatif, dengan menggunakan seluruh subjek sebagai populasi. Jadi penelitian ini merupakan penelitian populasi. Subjek penelitian adalah 1 orang kepala sekolah, 95 orang siswa kelas 1 sampai dengan kelas 6, dan 7 orang guru di SD Lazuardi Tursina Banyuwangi. Metode pengumpulan data menggunakan wawancara, observasi, dan dokumentasi pelaksanaan pembelajaran responsif gender dan kesehatan reproduksi serta dokumentasi. Data yang telah dikumpulkan dianalisis dengan analisis interaktif melalui tiga tahapan yaitu reduksi data, penyajian data, dan penarikan kesimpulan. Keabsahan data diperoleh dari memperpanjang waktu dalam proses pengamatan yang dilakukan secara berkelanjutan dan diuji dengan triangulasi.

\section{HASIL DAN PEMBAHASAN}

\section{Hasil}

SD Lazuardi Tursina Banyuwangi mengimplementasikan pendidikan responsif gender dan kesehatan reproduksi melalui pelaksanaan pembelajaran yang responsif, integrasi pada matapelajaran, dan hidden kurikulum. Berdasarkan hasil penelitian yang dilakukan, penjelasan dari ketiga strategi implementasi pendidikan resposif gender dan kesehatan reproduksi di SD Lazuardi Tursina dapat dijelaskan berikut ini. Pertama pelaksanaan pembelajaran yang responsif ditunjukkan dengan guru menyiapkan berbagai pendekatan pembelajaran yang dapat memenuhi kaidah kesetaraan dan keadilan gender.elaksanaan proses pembelajaran yang responsif dapat meningkatkan pemahaman siswa terhadap kesetaraan gender. Anak laki-laki dan perempuan berada dalam iklim belajar yang saling menghargai. Anak laki-laki dan perempuan memiliki peluang yang sama untuk berpartisipasi aktif dalam proses pembelajaran. Selama kegiatan pembelajaran berlangsung baik anak laki-laki maupun perempuan harus ditawarkan kesempatan yang sama tanpa memandang jenis kelamin dan sifat permainan (Nguyen, 2021; Tagliacozzo \& Tullio, 2021). Di SD Lazuardi Tursina siswa laki-laki dan perempuan memiliki kesempatan yang sama untuk menyelesaikan project apapun sesuai dengan mata pelajaran yang sedang dipelajari. Dinamika dalam kelompok seperti siapa yang akan memimpin kelompok, siapa yang akan mempresentasikan hasil project, dan lain-lain diserahkan kepada siswa. Dalam hal ini guru memberikan kebebasan dan kesempatan yang sama kepada anak laki-laki dan anak perempuan untuk memilih peran, seperti diungkapkan oleh Pangastuti. Hal ini menunjukkan bahwa penyelenggaraan pendidikan di SD Lazuardi Tursina telah mengimplementasikan pendidikan responsif gender. Guru telah menyediakan ruang untuk seluruh siswa ikut serta dalam proses pembelajaran yang dilakukan. Guru mendorong partisipasi siswa dan memberikan kesempatan yang sama bagi anak laki-laki maupuan anak perempuan dengan memperhitungkan kebutuhan spesifik gender anak laki-laki dan perempuan di dalam kelas (Muafiah et al., 2021).

Pengaturan tempat duduk dalam ruang kelas di SD Lazuardi Tursina tidak membatasi posisi seperti ditunjukkan pada Gambar 1. Barisan depan atau belakang tidak identik dengan jenis kelamin tertentu. Anak laki-laki dan perempuan dapat memilih sendiri apakah mereka akan berada pada barisan depan atau belakang. Pengaturan tempat duduk ini menunjukkan bahwa semua manusia sama, tidak ada manusia kelas satu (laki-laki) dan manusia kelas 2 (perempuan). Anak laki-laki maupun perempuan harus diberdayakan, mempraktikkan kesetaraan gender dan mempromosikan hak asasi manusia dan demokrasi di sekolah (Barreiro-Gen et al., 2021; Ratnawati et al., 2019). Tata tertib belajar di SD Lazuardi Tursina disepakati bersama oleh seluruh siswa. Dalam penyusunan tata tertib siswa perempuan berhak mengajukan pandangan terutama yang menyangkut kebutuhan pribadi perempuan. Hal yang menyangkut kebutuhan perempuan ini misalnya kesepakatan tentang aturan waktu yang dibutuhkan untuk ke kamar mandi bagi anak perempun dan anak laki-laki, dan keamanan bagi anak saat berganti pakaian setelah olah raga. Kesepakatan ini menunjukkan telah adanya rasa saling menghormati antara siswa laki-laki dan perempuan. Masing-masing mengetahui bahwa setiap orang memiliki kebutuhan pribadi yang harus dihargai. Hal ini bertujuan melakukan penyertaan siswa dan penciptaan lingkungan belajar yang responsif seperti pada Gambar 2. Kedua, pendidikan gender dan kesehatan reproduksi di SD Lazuardi Tursina dilakukan melalui integrasi dalam mata pelajaran. Pada mata pelajaran IPA materi mengenal angota tubuh guru mengenalkan secara jujur kepada anak anggota tubuh manusia. Misalnya menggunakan kata alat kelamin untuk mengenalkan penis dan vagina, tidak menggunakan kata "burung" ; menggunakan kata payudara tidak menggunakan kata "nenen", menggunakan kata Rahim serta mengenalkan fungsi dari alat reproduksi tersebut secara benar menurut perpspektif kesehatan. Pada mata pelajaran Agama, guru memberikan waktu khusus untuk membahas masalah keputrian dan keputraan serta memberikan pendampingan terhadap siswa yang baru mengalami menstruasi bagi siswa perempuan dan mimpi basah bagi siswa laki-laki (Wibowo, 2011). 


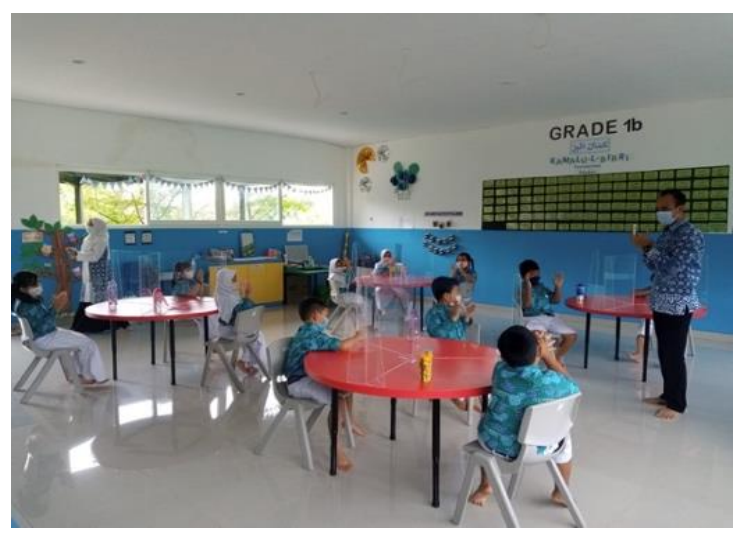

Gambar 1. Pengaturan Tempat Duduk yang Responsif

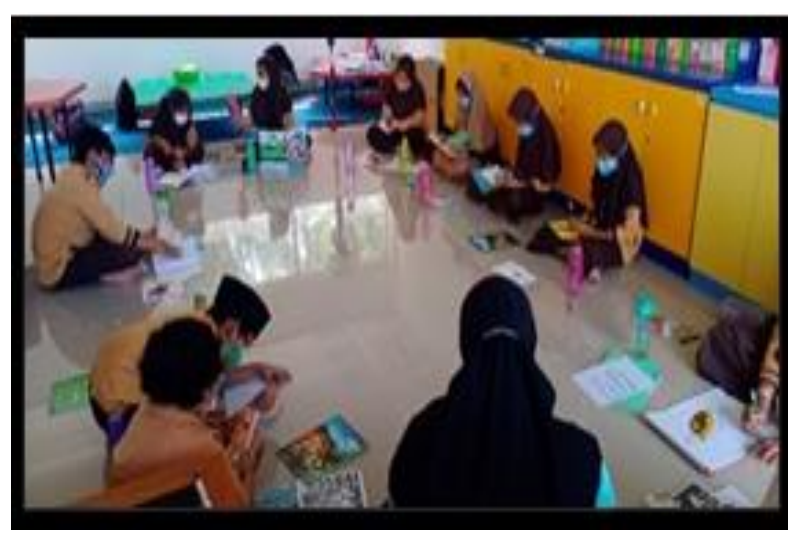

Gambar 2. Penyertaan Siswa dan Penciptaan Lingkungan Belajar yang Responsif

Pengintegrasian pendidikan kesehatan reproduksi dalam mata pelajaran ini dipandang tepat untuk memberikan pemahaman kepada siswa tentang hal apa yang boleh dan tidak boleh orang lain lakukan terhadap dirinya terutama menyangkut kesehatan reproduksinya, termasuk bagaimana menjaga dari kekerasan sexsual selama di sekolah. Melalui pengintegrasian dalam mata pelajaran, diketahui bahwa anak-anak dapat lebih cepat memperoleh kesadaran tentang hak-hak reproduksinya. Anak-anak usia dini dapat menunjukan bagian tubuh tertentu yang boleh dan tidak boleh disentuh orang lain setalah memperoleh pendidikan kesehatan reproduksi dan terhindar dari perilaku bulliying serta kekerasan sexsual di sekolah (Hinga, 2019; Tjahjono \& Nita, 2019). Pada mata pelajaran IPS nilai-nilai gender disampaikan secara universal. Misalnya pada kompetensi dasar mengungkapkan perasaan guru memberikan keterangan bahwa anak laki-laki boleh mengungkapkan rasa sedih dengan menangis, pada tema keluargaku, guru menunjukkan bahwa tanggung jawab terhadap keluarga adalah tanggung jawab orang tua. Hal ini penting karena situasi siswa bisa berbeda, antara siswa dengan orang tua lengkap dan orang tua tunggal seperti yang diungkapkan oleh Pangastuti. Pada pelajaran jasmani guru memberikan kesempatan yang sama kepada anak perempuan untuk perkembangan motorik dengan kegiatan lari, lompat, dan lempar. Berdasarkan hasil wawancara terungkap bahwa semua siswa mendapat kesempatan untuk melakukan kegiatan fisik sesuai kemampuannya. Startegi implementasi pendidikan responsif gender dan kesehatan reproduksi yang dilakukan di SD Lazuardi Tursina Banyuwangi ini sejalan dengan penelitian lain yang menyatakan bahwa guru dapat mengajarkan kesehatan reproduksi secara terintegrasi pada mata pelajaran IPA, Agama, dan Pendidikan Kesehatan Jasmani.

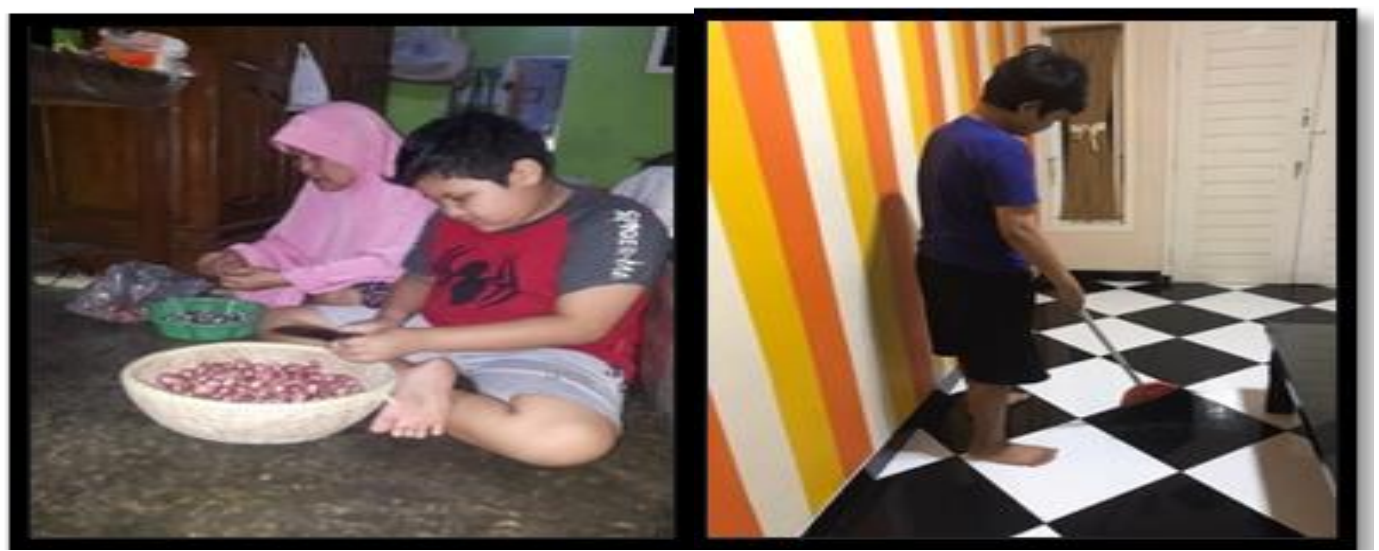

Gambar 3. Hidden Kurikulum berupa compassionated action yang dilakukan oleh siswa di rumah

Ketiga, pendidikan responsif gender dan kesehatan reproduksi di SD Lazuardi Tursina dilakukan dengan penerapan Hidden kurikulum dalam bentuk compassionated action. Siswa diberikan satu misi khusus setiap hari oleh guru misalnya mencuci bekas piring makan sendiri, membersihkan tempat tidur sendiri, menyapu kamar sendiri. Misi ini berlaku untuk semua siswa laki-laki dan perempuan. Dengan demikian siswa dapat memahami bahwa tugas domestik di dalam rumah merupakan tanggungjawab semua anggota keluarga, bukan tanggung jawab ibu dan anak perempuan saja. Penerapan hidden 
kurikulum ini merupakan cara untuk menciptakan pembiasaan responsif gender dalam kehidupan siswa sehar-hari seperti ditunjukkan pada Gambar 3. Guru dapat melengkapi dan menyediakan metode serta strategi hidden kurikulum yang diterapkan melalui pemberian kesempatan kepada siswa untuk mempraktikkan atau menerapkan satu misi khusus setiap hari.

Implikasi dari pelaksanaan pendidikan responsif gender dan kesehatan reproduksi yang telah dilaksanakan antara lain adalah siswa dapat memahami dan menunjukkan pola relasi gender dengan tepat, menghargai teman tanpa memandang jenis kelamin, dan mengembangkan potensi yang dimiliki secara optimal. Baik siswa laki-laki maupun perempuan mendapatkan hak dan layanan yang sama selama proses pembelajaran berlangsung. Penerapan pendidikan responsif gender dan kesehatan reproduksi di sekolah juga dapat menstimulasi perkembangan sosial siswa agar siswa dapat tumbuh menjadi pribadi yang tangguh dan siap menghadapi kehidupan sesungguhnya di masa-masa yang akan dating (Fitrianti \& Habibullah, 2012; Heo \& Toomey, 2020). Praktik-praktik pendidikan responsif gender yang dilaksanakan relatif mudah diimplementasikan oleh guru di sekolah. Penelitian ini belum melihat bagaimana respon orang tua terhadap praktik-praktik pendidikan gender dan kesehatan reproduksi yang telah diimplementasikan.

\section{SIMPULAN}

Pendidikan responsif gender dan kesehatan reproduksi yang mengintegrasikan pesan gender dan kesehatan reproduksi pada mata pelajaran dan merancang hidden kurikulum efektif untuk memberikan pemahaman gender dan kesehatan reproduksi bagi siswa di sekolah dasar. Pembelajaran responsif gender dan kesehatan reproduksi akan membantu anak-anak memiliki pemahaman yang tepat tentang peran gender dan fungsi kesehatan reproduksinya sehingga anak dapat menjalankan kehidupan dengan pola relasi gender yang tepat dikemudian hari.

\section{DAFTAR PUSTAKA}

Abraha, M., Dagnew, A., \& Seifu, A. (2019). Gender Responsive Pedagogy: Practices, Challenges \& opportunities- A Case of Secondary Schools of North Wollo Zone, Ethiopia. Journal of Education, Society and Behavioral Science, 30(3), 1-17. https://doi.org/10.9734/jesbs/2019/v30i330128.

Barreiro-Gen, M., Lozano, R., Temel, M., \& Carpenter, A. (2021). Gender equality for sustainability in ports: Developing a framework. Marine Policy, 131, 104593. https://doi.org/10.1016/j.marpol.2021.104593.

Dary, A. W., \& Ilyas, F. (2019). Pengaruh Gender, Penghargaan Finansial Dan Pertimbangan Pasar Kerja Terhadap Minat Mahasiswa Akuntansi Untuk Berkarir Menjadi Akuntan Publik Dan Non Akuntan Publik. Jurnal Akuntansi, 7(1), 51-60. https://doi.org/10.33369/j.akuntansi.7.1.51-60.

Dorji, T. (2020). Gender Responsive Pedagogy Awareness and Practices: A Case Study of a Higher Secondary School under Thimphu Thromde, Bhutan. International Journal of Linguistics and Translation Studies, 1(2), 100-111. https://doi.org/10.36892/ijlts.v1i2.21.

Fitrianti, R., \& Habibullah, H. (2012). Ketidaksetaraan Gender dalam Pendidikan; Studi Pada Perempuan di Kecamatan Majalaya Kabupaten Karawang. Sosio Konsepsia: Jurnal Penelitian Dan Pengembangan Kesejahteraan Sosial, 17(1), 85-100. https://doi.org/10.33007/ska.v17i1.809.

Fujiati, D. (2016). Seksualitas Perempuan dalam Budaya Patriarkhi. MUWAZAH : Jurnal Kajian Gender, 8(1), 26-47. http://e-journal.iainpekalongan.ac.id/index.php/muwazah/article/view/734.

Hasanah, H. (2016). Pemahaman Kesehatan Reproduksi bagi Perempuan: Sebuah Strategi Mencegah Berbagai Resiko Masalah Reproduksi Remaja. Sawwa Jurnal Studi Gender, 11(2), 229-252. https://doi.org/10.21580/sa.v11i2.1456.

Heo, M., \& Toomey, N. (2020). Learning with multimedia: The effects of gender, type of multimedia learning resources, and spatial ability. Computers and Education, 146, 103747. https://doi.org/10.1016/j.compedu.2019.103747.

Hinga, I. A. T. (2019). Pencegahan kekerasan seksual pada anak melalui edukasi kesehatan reproduksi berbasis media pada murid sekolah pendidikan anak usia dini. Gemmasika, 3(1), 83-98. https: //doi.org/10.30787/gemassika.v3i1.395.

Huntera, M., \& Morrell, R. (2021). Corporal punishment and gender equality: regimes of care and rights in South African schools. Journal of Gender Studies, 30(3), 344-357. https: //doi.org/10.1080/09589236.2020.1867832.

Kahamba, J. S., Massawe, F. A., \& Kara, E. S. (2017). Awareness and Practice of Gender Responsive Pedagogy in Higher Learning Institutions: The Case of Sokoine University of Agriculture, 
Tanzania. Journal of Education, Humanities and Science, 6(2), 1-16. http://www.suaire.sua.ac.tz/handle/123456789/2405.

Lee, Y., Capraro, R. M., \& Bicer, A. (2019). Gender difference on spatial visualization by college students' major types as STEM and non-STEM: a meta-analysis. International Journal of Mathematical Education in Science and Technology, 50(8), 1241-1255. https: //doi.org/10.1080/0020739X.2019.1640398.

Muafiah, E., Puspita, A. R., Wanda, V. V., \& Damayanti. (2021). Gender Equality and Social Inclusion (GESI) Pada Dua Sekolah Inklusi Di Ponorogo. Musãwa Jurnal Studi Gender Dan Islam, 19(2), 141-156. https://doi.org/10.14421/musawa.2020.192.141-156.

Nguyen, C. P. (2021). Gender equality and economic complexity. Economic Systems, 100921. https://doi.org/10.1016/j.ecosys.2021.100921.

Olii, N., Rasyid, P. S., Yulianingsih, E., \& Sujawati, S. (2021). Pemberdayaan Remaja Desa Dalam Upaya Peningkatan Kesehatan Reproduksi dan Pencegahan Covid-19. Jurnal Masyarakat Mandiri, 5(1). https://doi.org/10.31764/jmm.v5i1.3742.

Ratnawati, D., Sulistyorini, S., \& Abidin, A. Z. (2019). Kesetaraan Gender Tentang Pendidikan Laki-laki dan Perempuan. Jurnal Harkat: Media Komunikasi Gender, 15(1), 10-23. https://ejournal.metrouniv.ac.id/index.php/tarbawiyah/article/view/420.

Tagliacozzo, S., \& Tullio, I. (2021). Gender equality plans (GEPs) as a framework to devise gender equality measures for disaster research. International Journal of Disaster Risk Reduction, 60, 102294. https://doi.org/10.1016/j.ijdrr.2021.102294.

Tjahjono, S., \& Nita, V. (2019). Pencegahan bullying di sekolah dasar melalui pendidikan kesehatan reproduksi. Jurnal Komunikasi Pendidikan, 3(1), 65-75. https://doi.org/10.32585/jkp.v3i1.256.

Tshewang, D. (2020). Gender Responsive Pedagogy Awareness And Practices: A Case Study Of A Higher Secondary School Under Thimphu Thromde, Bhutan. International Journal of Linguistics And Translation Studies, 1(2), 100-110. https://doi.org/10.36892/ijlts.v1i2.21.

Wibowo, D. E. (2011). Peran Ganda Perempuan dan Kesetaraan Gender. MUWAZAH : Jurnal Kajian Gender, 3(1), 357-364. http://e-journal.iainpekalongan.ac.id/index.php/Muwazah/article/view/6\%3E. 